\title{
Małgorzata Ogonowska: „Byłem już w myśli pozbawiony posady i w ostatniej nędzy". Nie tylko o finansach Brunona Schulza głos drugi
}

„Co Was, u licha, gnębi?” - pytacie'.

Interesujący i prowokacyjny tekst Piotra Sitkiewicza ${ }^{2}$ na temat sytuacji materialnej Schulza skłonił mnie do przyjrzenia się tej samej sprawie. $Z$ wieloma zawartymi tam opiniami i interpretacjami trudno mi się zgodzić - i to na wielu poziomach. Kilka przykładów: według autora Schulz „był ofiarą "płaczliwej niemęskości, recydywy zwątpienia», a przynajmniej miał za taką ofiarę uchodzić w swym autoportrecie" (s. 127). Przesadzał, postrzegając swą sytuację finansową jako trudną, bo „gdy [artysta] żył skromnie, dysponując takimi sumami jak Schulz, mógł mieć poczucie komfortu, zwłaszcza gdy żył na prowincji, gdzie ceny były wyraźnie niższe niż w stolicy ${ }^{3}$ i gdzie brakowało pokus do trwonienia pieniędzy” (s. 131). Podobnie mój sprzeciw budzi fragment: „Schulz nie był nieudacznikiem, on jedynie odgrywał rolę nieudacznika. Słowne samobiczowanie, które uprawia w kontaktach międzyludzkich, najwyraźniej musiało dawać mu ulgę lub satysfakcję, skoro tak często i z takim upodobaniem z niego korzystał. Musiało wywoływać pożądane wrażenie na jego rozmówcach. Ale na pewno nie miał obiektywnych powodów do tego, by uprawiać swoje codzienne masochistyczne nabożeństwo. Maska nieszczęśliwego nieudacznika widoczna jest również w jego stosunku do kwestii materialnych, do pieniędzy i pracy zarobkowej. Schulz

1 Z listu do Zenona Waśniewskiego, 5 czerwca 1934. Cyt. za: B. Schulz, Dzieła zebrane, t. 5: Księga listów, zebrał i przygotował do druku J. Ficowski, uzupełnił S. Danecki, Gdańsk 2016, s. 69-70 (KL I, 29).

2 "Jednakowoż bez pieniędzy". Sytuacja materialna Brunona Schulza, s. 126-135 niniejszego numeru "Schulz/Forum".

3 Nie zawsze, jak pozwala sądzić artykuł opublikowany w "Chwili" z 7 stycznia 1928 roku (nr 3159, s. 10): Rozpiętość cen w Polsce. Dlaczego panuje drożyzna? Warszawa i Drohobycz najdroższymi miastami (https://libraria.ua/numbers/6/26522/?PageNumber=10\&Articleld=986757; dostęp: 3 grudnia 2018). 
tą trywialną sferą jawnie pogardza, lecz potrafi zapewnić w miarę komfortowe życie sobie i swojej rodzinie" (s. 134). Zupełnie inaczej niż Piotr Sitkiewicz postrzegam również depresję Schulza.

Nie będę jednak polemizowała z konkretnymi fragmentami tego artykułu, za to postaram się zwrócić uwagę na kwestie, które pozwalają - jak sądzę - postrzegać życiowe, finansowe i psychologiczne status quo Schulza w odmienny sposób. Moim zdaniem, jeśli nie traci się z pola widzenia szczegółów, które poniżej pokrótce przywołam 4 , mniej pochopnie ulega się pokusie kwitowania jego postawy stwierdzeniem, że „wszelka niemoc Schulza pochodziła nie z zewnątrz, ze złego i okrutnego świata [...], ale z jego wnętrza, w którym mieszkały prawdziwe demony. Doświadczał grozy rzeczywistości nawet tam, gdzie owej grozy nie było" (s. 134).

\section{Księga rachunkowa}

Co o finansach Schulza wiadomo na pewno? Niestety niewiele. Wiadomo co prawda, ile zarabiał jako nauczyciel (od 240 do 300 zł5), ile mogły wynosić jego honoraria autorskie (nic plus poniesione koszty w wypadku Sklepów cynamonowych; 1500 złotych za Sanatorium pod Klepsydra; po 100 złotych za teki Xięgi bałwochwalczej; jakieś 15 groszy za wiersz tekstu do prasy; za prelekcje około 50 złotych, bo tyle dostał za odczyt o Gombrowiczu w 1938 roku$^{6}$ ), jak wysokie były uzyskane stypendia (na przykład w 1936 roku 150 złotych77). Nie jest tajem-

4 Pokrótce, ponieważ podjęty temat znacznie przekracza ramy artykułu. Z tego powodu zrezygnowałam między innymi z przywoływania analiz socjologicznych i historycznych związanych z kwestiami biedy, ubóstwa, różnic społecznych, obiektywnym i subiektywnym postrzeganiem pozycji materialnej, kwestiami poczucia bezpieczeństwa finansowego i życiowego, historycznym i współczesnym ich rozumieniem itd., choć przygotowując się do dyskusji, sięgnęłam między innymi po teksty z tomów Zrozumieć biednego. O dawnej i obecnej biedzie w Polsce (pod red. E. Tarkowskiej, Warszawa 2000), Bieda i bogactwo w polskiej kulturze i świadomości (red. G. Skąpska, Kraków 2003), Bogactwo i bieda. Próba refleksji humanistycznej (pod red. nauk. R. Borkowskiego, Kraków 2004). Również wskazując na konteksty biograficzne, historyczne, społeczne, gospodarcze itp., wybieram tylko niektóre przykłady i skromniej, niżbym chciała, popieram je przywołaniami z literatury przedmiotu. Słowem: świadomie nie zmierzam tutaj do wyczerpania tematu i argumentacji.

5 Por. KL I, 29, s. 70; KL I, 90, s. 153; KL II, 9, s. 233-234.

6 Por. KL I, 29, s. 70 („Ze Sklepów cynam. nie miałem ani grosza. Przeciwnie kosztowały mnie one kilka wyjazdów do Warszawy"); KL, s. 326, przypis 4; z listu Michała Chajesa do Jerzego Ficowskiego z 7 czerwca 1948 roku (dzięki uprzejmości prof. Jerzego Kandziory); KL I, 75, s. 132 (w 1938 roku według takiej stawki wylicza honorarium, na jakie może liczyć Ludwik Lillle za publikację w „Tygodniku llustrowanym”); KL I, 95, s. 161 („Za odczyt dostałem 50 zł, potem Melcer robiła mi wymówkę, że za krótko trwało").

7 Por. KL I, 66, s. 112. Por. też: „W odpowiedzi na to pozwalam sobie zauważyć, że roczne stypendium ministerialne, które otrzymałem, w połączeniu z nadwyżką dochodów mego szczebla służbowego ponad pobory siły kontraktowej stanowi zaledwie minimum utrzymania dla mnie i mojej rodziny. [...] Urlop bezpłatny, ograniczając moje dochody do samego stypendium, skazałby mnie na marną wegetację, zmusiłby do szukania ubocznych dochodów w pracy dziennikarskiej" (KL II, 14, s. 238). 
nicą, że przez lata wspierał go dobrze sytuowany brat ${ }^{8}$. Ale informacje te - ciągle przecież niepełne i nie do końca precyzyjne - stanowią zaledwie jedną kolumnę księgi rachunkowej Schulza. Nie zachowały się bowiem (lub nie są dotychczas znane) osobiste dokumenty, notatki czy rachunki wprost dokumentujące jego sytuację materialną, które jednoznacznie potwierdziłyby, ile wydawał na życie, codzienne potrzeby swoje i rodziny, na utrzymanie domu (także niezbędne naprawy, ogrzewanie, prąd ${ }^{9}$ ), na podróże oraz krótsze wyjazdy osobiste i w sprawach zawodowych (nauczycielskich, artystycznych, literackich), na leczenie, książki ${ }^{10}$, kulturę i rozrywkę, samokształcenie, artykuły potrzebne do pracy zawodowej i artystycznej, przyjemności, dobroczynność ${ }^{11}$... Wreszcie - czy miał oszczędności, czy może borykał się z długami ${ }^{\mathbf{1 2}}$. O skali wydatków można jedynie spekulować na podstawie źródeł zewnętrznych, takich jak dane statystyczne, informacje prasowe, zachowane dokumenty. Systematyczne i szeroko zakrojone kwerendy z pewnością pozwoliłyby ustalić wiele szczegółów przybliżających badacza do wiedzy o finansach Schulza. Byłaby to jednak ciągle wiedza $\mathrm{z}$ drugiej ręki, która nie odpowiadałaby chociażby na pytania o to, co, gdzie i za ile Schulz kupował, w jaki sposób podejmował decyzje finansowe, co uznawał za priorytet.

Pewne światło na te kwestie rzucają oczywiście wzmianki i ślady w zachowanych listach Schulza i do Schulza. Tu jednak kolejna niedogodność. Wyłaniający się z nich obraz jest niepełny nie tylko dlatego, że nie zawiera odpowiedzi na wszystkie pytania, które nasuwają się w tej materii, ale także dlatego, że świadectwa te dotyczą stosunkowo krótkiego okresu, pełne są luk i niewiadomych. Wypowiedzi samego Schulza, w których można poszukiwać informacji bezpośrednio odnoszących się do jego sytuacji ekonomicznej i stosunku do tej sfery życia, są ograniczone do lat 1921-1941 (to daty pierwszego i ostatniego z zachowanych listów) i wcale nie tak liczne. W dodatku pierwsza jednoznaczna wzmianka o finansach pojawia się dopiero w korespondencji do

8 Por. KL I, 3, s. 39; KL I, 39-40, s. 83-84.

9 Por. interesującą notkę Drohobycz płaci za wiele za prąd elektryczny!, "Chwila” z 21 stycznia 1938 (nr 1047, wydanie wieczorne), s. 10 (https://libraria.ua/numbers/866/31580/?PageNumber=10\&Ar ticleld=1366545\&Search=drohobycz; dostęp: 3 grudnia 2018).

10 Z listu do władz szkolnych z 30 listopada 1936: „Prywatne środki nawet dobrze uposażonego człowieka nie wystarczają do zaopatrywania się w potrzebną lekturę" (KL II, 18, s. 242).

11 Ślad takiego zaangażowania znajduje się w albumie dokumentującym zbiórkę na dożywianie dzieci zorganizowaną przez Związek Pracy Obywatelskiej Kobiet w Drohobyczu z okazji imienin Józefa Piłsudskiego. Z tego źródła wynika, że Schulz ofiarował na ten cel 2 złote (http://www. szukajwarchiwach.pl/2/109/0/2.1/76?q=drohobycz+XSKANro:t\&wynik=10\&rpp=15\&page=1\# tabJednostka; dostęp: 3 grudnia 2018).

12 Bo chyba zdarzało mu się pożyczać pieniądze: „Mam kłopot z wyborem miejsca spędzenia urlopu. Mam bardzo ograniczone środki - (nie mam jeszcze nic, pożyczę sobie)" (z listu do Romany Halpern z 30 czerwca 1939). 
władz szkolnych z 9 lutego 1934 roku (KL II, 9, s. 233-234), ostatnia - w liście do Anny Płockier z 23 września 1941 roku, w którym Schulz się tłumaczy: „Nie odpisałem zaraz z śmiesznej przyczyny braku paru groszy na kartkę” (KL I, 140, s. 211).

Przykłady już przytoczone przez Piotra Sitkiewicza ${ }^{\mathbf{1 3}}$ i przywołane przeze mnie w kilku pierwszych akapitach można uzupełnić przynajmniej o kilka istotnych cytatów. Z całym rozmysłem przywołuję je tutaj prawie wszystkie i w kolejności chronologicznej, niemal bez komentarza, by z uwagą wsłuchać się w głos Schulza.

W liście z 5 czerwca 1934 roku Schulz pisze do Zenona Waśniewskiego: „Co zrobię podczas feryj - nie wiem jeszcze. [...] Może pojadę do Zakopanego, ze względu na zdrowie. Zależy to od tego, czy otrzymam subwencję na to" (KL I, 29, s. 70).

24 czerwca 1935 temu samemu adresatowi tak przedstawia swą sytuację: „Był to [urlop] szczyt moich marzeń, tymczasem sprawa nie przedstawia się tak różowo, jak myślałem. Będę miał niespełna $200 \mathrm{zł}$ miesięcznie (przez 10 miesięcy). Byłoby to dla mnie wystarczające, gdyby nie to, że z tego muszę utrzymać też dom mojej siostry, która mieszka ze mną z siostrzeńcem i z kuzynką" (KL I, 42, s. 86).

13 lipca 1935 pisze do Waśniewskiego: „Oboje jesteśmy biedni, ona [Szelińska] jest zredukowaną nauczycielką gimnazjalną i szuka posady" (KL I, 43, 87).

11 kwietnia 1936 informuje Kazimierza Truchanowskiego: „Oprócz mojej artystycznej bezpłodności ciąży na mnie wiele kłopotów materialnych i życiowych tak np. na przyszły miesiąc nie otrzymam już stypendium (150 zł) i przez kilka miesięcy nie będę miał z czego żyć, bo i pensji teraz nie pobieram. [...] Stoję teraz przed trudnym problemem małżeńskim, połączenie z kochającą i dzielną, niezwykłą kobietą jest zachwiane z powodu mych stosunków materialnych" (KL I, 66, s. 112).

W listopadzie tego samego roku zwierza się Romanie Halpern: „Nie chcę się skarżyć, ale ja żyję w bardzo ciasnych i krępujących warunkach. Mieszkam w 2 pokojach ze siostrą wdową, bardzo miłą osobą, ale chorą i smutną, ze starszą kuzynką, która prowadzi nam gospodarstwo i z siostrzeńcem, 26-letnim młodzieńcem, który jest czymś w rodzaju melancholika. Dlatego zdaje mi się, że małżeństwo będzie dla mnie zmianą na lepsze. Nie wiem tylko czy podołam utrzymać dwa domy, gdyż moja rodzina jest bez żadnych dochodów" (KL I, 81, s. 139-140).

$13 \mathrm{KL} \mathrm{I}$, 29, s. 70 (wysokość nauczycielskiej pensji); KL I, 30, s. 71 (informacja o kupnie losów); KL I, 87, s. 148 (rozterki co do wyjazdu do Halpern); KL I, 90, s. 153 (powody odrzucenia propozycji pracy w Warszawie; nauczycielskie uposażenie); KL I, 99, s. 166 (nadzieje na nagrodę); KL I, 106, s. 176 (tapczan vs Paryż); KL II, 9, s. 233 (uposażenie). 
W kolejnych latach do tej samej adresatki pisze o swym położeniu jeszcze wielokrotnie.

24 lipca i 3 sierpnia 1937 (odpowiednio) nawiązuje do ograniczeń i skrępowania, które sprawiają, że plan odwiedzin u Halpern jest trudny do zrealizowania: „Naturalnie że chętnie bym się z Panią zobaczyl, ale moja ruchomość jest b. ograniczona z powodu braku pieniędzy" (KL I, 86, s. 147); na jego obawy wpływają „ograniczone środki pieniężne, konieczność liczenia się z pieniędzmi, narażenia Pani na koszta" (KL I, 87, s. 148).

Kiedy ta proponuje mu załatwienie pracy w Warszawie, odmawia, tłumacząc się w liście z 30 sierpnia 1937: „Powiedziałem już Pani kiedyś, że mam 3 osoby na utrzymaniu (siostrę, kuzynkę, siostrzeńca), których nie mogę porzucić zupełnie na łaskę losu. Zarabiam teraz około $300 \mathrm{zł} \mathrm{miesięcznie.} \mathrm{Gdybym} \mathrm{otrzymał}$ w Warszawie zajęcie na podobnych warunkach - wyjechałbym, gdyż za 200 zł mógłbym się tam utrzymać, a 100 zł posyłałbym rodzinie. U p. Ramberga miałbym jednak 2 do 6 godzin - zarabiałbym co najwyżej 100 zł. Dla tych paru godzin nie mogę porzucać państwowej posady (VII stop. służb.) która mi zapewnia emeryturę. Nie mam odwagi dostatecznej, dostatecznego impulsu czy podniety, żeby tak ryzykowny krok uczynić” (KL I, 90, s. 153).

Ale nawet ta pensja i różne do niej dodatki ${ }^{14}$ nie pozwalały na zaspokojenie prozaicznych potrzeb, czego można się domyślać z listu do Halpern z 10 marca 1938 roku: „Urządzam sobie w naszym domu osobny pokój, ale przerażają mnie koszta: tapczan itd. Mam duży, jasny pokój i część mebli, brak mi tapczana, firanek, jakiegoś dywanu" (KL I, 101, s. 169). Warto sobie uświadomić, że Schulz ma wówczas czterdzieści sześć lat.

Podróż do Paryża była nie tylko logistycznym, lecz także finansowym wyzwaniem, które zmuszało do poszukiwania oszczędności. 19 maja 1938 roku Schulz pisze do Halpern: „Chcę koniecznie z końcem czerwca pojechać na 2-3 tygodnie do Paryża. [...] Nie wiem tylko jak dostać paszport ulgowy. Zdaje mi się, że Ty masz w Ministerstwie Spr. Zewn. jakieś konneksje. Czy nie mogłabyś się dowiedzieć, w jaki sposób w prędkiej drodze mógłbym dostać paszport zagraniczny ulgowy? Czy na rysunki, które będę woził ze sobą potrzeba jakiegoś pozwolenia? 66\% procentową [sic!] zniżkę kolejową na kol. polskich dostanę za pośredn. Związku zaw. literatów. Można także w ambasadzie francuskiej starać się o zniżkę kolejową na kolejach franc., ale nie wiem, jak się to robi” (KL I, 105, s. 174). Potwierdza się to w liście do Władysława Zawistowskiego z 21 czerwca 1938 roku: „Gdy obecnie jestem w możności skromne honorarium autorskie za książkę obrócić na parutygodniowy pobyt we Francji, napotykam na wielkie trudności ze strony obowiązujących przepisów. Centrala dewiz od- 
mówiła mi udzielenia potrzebnych akredytyw, od posiadanej zaś akredytywy uzależnia starostwo przyznanie turystycznego (ulgowego) paszportu" (KL I, 62, s. 102-103).

Zestawienie przywołanych fragmentów pozwala się zgodzić z opinią, że Schulz miał „stałą pracę, zapewniającą mu finansowanie podstawowych życiowych potrzeb” 15, że „na tle ówczesnej biednej Polski, w oczach większości swoich rodaków, [...] mógł uchodzić za bogacza" i że w istocie nie cierpiał na niedostatek większy niż ten, który był udziałem jemu podobnych osób - literatów, artystów łączących pracę twórczą z pracą zarobkową ${ }^{16}$. Ale czy Schulz, który wprost lub pośrednio charakteryzuje swą sytuację materialną jako złą, w istocie widzi ją tak właśnie, bo ulega podrażnionym nerwom i skłonności do postrzegania świata „przez czarny okular [...] pogłębiającej się depresji”"17? Albo wręcz dlatego, że wpada w jakąś autokreacyjną pozę?

Niekoniecznie. Wydaje się raczej, że sytuacja materialna Schulza - jakkolwiek z pewnością lepsza niż w wypadku wielu jego współczesnych - nie pozwalała na uzyskanie poziomu egzystencji uwalniającego od codziennych bytowych trosk. To były realne problemy, z którymi Schulz musiał się mierzyć i wobec których musiał podejmować takie czy inne decyzje wedle własnego osądu, możliwości i sił18. A także wedle własnej oceny stopnia życiowego bezpieczeństwa. Czy ten niepokój był nadmierny i czy nie miał racjonalnych podstaw?

\section{Grozy nie było? Kilka uwag o historycznych, gospodarczych i społecznych kontekstach życia Schulza}

O subiektywnym poczuciu bezpieczeństwa finansowego decydują nie tylko realne dochody, stosunek przychodów do kosztów i możliwość zabezpieczenia się na przyszłość. W grę wchodzą również indywidualne predyspozycje, cechy i doświadczenia, także te wyniesione $\mathrm{z}$ domu rodzinnego i z wczesnego dzieciństwa, oraz całokształt sytuacji osobistej, pozostawanie w określonych relacjach, siatce powiązań sąsiedzkich, zawodowych i przyjacielskich.

Budując obraz położenia materialnego i społecznego rodziny Schulza i jego samego, możemy zatem przybliżyć się do zrozumienia pisarza i jego wyborów życiowych. Niejednokrotnie są one oceniane surowo: jako asekuranckie, podszyte strachem i niezdecydowaniem, brakiem energii życiowej, wygodnictwem, wresz-

15 Ibidem, s. 128.

16 Ibidem, s. 130-131, 132.

17 Ibidem, s. 133.

18 Ważne wydaje się i to, że w korespondencji Schulza można znaleźć ślady empatycznego stosunku do finansowej sytuacji adresatów. Por. na przykład listy do Waśniewskiego z 28 stycznia 1935 (KL I, 39, s. 83), 24 czerwca 1935 (KL I, 42, s. 87), 3 sierpnia 1935 (KL I, 44, s. 88), 7 sierpnia 1935 (KL I, 45, s. 89) czy 24 kwietnia 1938 (KL l, 49, s. 93). 
cie fałszywą, wystudiowaną pozą. Coś z tego wyraźnie pobrzmiewa również w tekście Piotra Sitkiewicza.

Mnie jednak niepokoje Schulza i jego wybory wydają się więcej niż zrozumiałe. Przyglądając się historii życia Schulza, rzuconej na tło ogólniejszych wydarzeń, dostrzegam, jak niewiele w niej stabilności, pewności jutra, powodów do optymizmu. Istotnym elementem tej historii jest zmienność losów i życiowego powodzenia, w czym można by upatrywać źródeł postawy, którą sam Schulz tak charakteryzuje w 1937 roku w liście do Romany Halpern: „Mnie brak nie tyle wiary w moje zdolności, ile czegoś ogólniejszego: $\mathrm{z}$ a u fan ia do życia, bezpiecznego spoczywania w swoim losie, wiary w ostate czną przychylność byt u. Miałem to dawniej, nawet o tym nie wiedząc. Ta wiara, to zaufanie otwiera w nas rezerwy twórczości, jest tym bogatym, sytym i ciepłym klimatem, w którym dojrzewają te późne i trudno dościgające owoce. Wypadki, w których niedobory życiowe, tragizmy stają się twórcze - są dla mnie niezrozumiałe. Ten rodzaj produktywności musi być całkiem inny od mojego" (KL I, 89, s. 151; podkreślenia moje - M. O.).

Jakież to „tragizmy” mogły pozbawiać Schulza „zaufania do życia” i zamykać przed nim „rezerwy twórczości”? Z pewnością - prócz codziennych trosk i kłopotów, będących udziałem wszystkich ludzi zawsze i wszędzie - spotykały go osobiste tragedie, takie jak śmierć ojca, samobójcza śmierć szwagra ${ }^{19}$, doświadczenie śmiertelnej choroby przyjaciół: Władysława Riffa i Emanuela Pilpla, śmierć matki, wreszcie brata. Musiał się mierzyć - jak wszyscy jemu współcześni - również z wydarzeniami pozostającymi poza bezpośrednim wpływem i decyzjami jednostki. Ale dlaczego zakładać, że ta powszechność bolesnych, niejednokrotnie traumatycznych doświadczeń - których Schulz był uczestnikiem i/lub świadkiem - nie stanowiła czynnika potęgującego (powodującego?) jego niepokoje i depresję?

By ująć rzecz najkrócej, poprzestanę na katalogu kilku dat, wyraźnie znaczących życie artysty: lata do 1914 roku, w których szczególną uwagę zwracają wypadki z 19 czerwca 1911 roku (krwawe wybory w Drohobyczu) ${ }^{20}$, lata 1914-1918 (wybuch I wojny światowej, życie uchodźcy w Wiedniu, poprzedzone nieznanymi nam wypadkami, które towarzyszyły tej drodze ${ }^{\mathbf{2 1}}$, zniszczenie Drohobycza w dzia-

19 Miała ona z pewnością liczne konsekwencje dla rodziny, również psychologiczne i społeczne, i nie wiązała się tylko z koniecznością zaopiekowania się owdowiałą Hanną i jej osieroconymi dziećmi.

20 Zob. M. Mściwujewski, Z dziejów Drohobycza, część II, z rysunkami J. S. Stupnickiego, Drohobycz 1939, s. 189; NN, Prawda o wyborach drohobyckich odbytych dnia 19 czerwca 1911 r., Lwów 1911, s. 34. Por. też poświęcony temu wpis Jakuba Orzeszka w „Kalendarzu życia, twórczości i recepcji Brunona Schulza" (https://schulzforum.pl/pl/kalendarz/19-czerwca-1911; dostęp: 3 grudnia 2018).

21 Por. wpisy kalendarzowe opracowane przez Joannę Sass: https://schulzforum.pl/pl/autorzy/joanna-sass (dostęp: 3 grudnia 2018). Tam też zestawienie zasiłków pobieranych przez Schulza z Centralnej Agencji Pomocy dla Uchodźców Wojennych z Galicji i Bukowiny. 
łaniach wojennych), lata 1919-1921 (powrót w rodzinne strony targane niepokojami), okres względnej stabilizacji od 1921 do 1935 roku, wreszcie czas od śmierci Izydora Schulza ${ }^{22}$ do wybuchu II wojny światowej i od września 1939 roku do śmierci Brunona.

Czy któraś z tych dat stała się momentem przełomowym? Raczej skłaniałabym się ku myśli, że proces utraty „wiary w ostateczną przychylność bytu” przebiegał powoli, zrazu niedostrzegalnie, przez sumowanie kolejnych doświadczeń czy traum, a wybuch II wojny światowej i wszystko to, co ona za sobą niosła - to już tylko potwierdzenie i urzeczywistnienie groźnego scenariusza, nie tyle przeczuwanego, ile właśnie doświadczanego i obserwowanego. I to, jak sądzę, od wczesnych lat życia.

W 1905 roku Schulz był trzynastolatkiem, uczniem drohobyckiego gimnazjum. Z łatwością można by więc założyć, że wypadki tego czasu ani go jakoś szczególnie nie interesowały, ani nie miały na niego żadnego wpływu. Ale czy $\mathrm{w}$ istocie mogły zupełnie przejść bez echa?

Po 22 stycznia 1905 roku (krwawa niedziela w Petersburgu) „przez wiele miast galicyjskich od Stanisławowa i Drohobycza poprzez Lwów, Jarosław, Tarnów, Nowy Sącz aż po Kraków i Chrzanów przeszły [...] demonstracje, pochody i manifestacje uliczne, solidaryzujące się z walczącymi robotnikami Królestwa Polskiego i Rosji"23. W dodatku ta napięta sytuacja w Drohobyczu i okolicach nie była niczym nowym. W mieście dochodziło już do strajków robotniczych, między innymi w styczniu i czerwcu 1901 roku $^{24}$. W 1902 docierały tutaj echa dramatycznie przebiegających strajków we Lwowie, połączonych „z rozruchami głodowymi, napadami na sklepy i wozy z pieczywem, z demonstracjami i walkami ulicznymi"25. W czerwcu 1904 roku strajkowali górnicy w kopalniach wosku ziemnego, w lipcu - górnicy naftowi w całym okręgu borysławskim. Wówczas też „skoncentrowano w powiecie drohobyckim i krośnieńskim oddziały wojskowe i żandarmów”26. W studium opracowanym „na podstawie referatu złożonego Delegacji Polskiej na Konferencję Pokojową w Paryżu” Zofii Daszyńskiej-Golińskiej można znaleźć informację o intensywności tych ruchów: „Statystyka strajków w Galicji, prowadzona szczegółowiej od rosyjskiej, wykazuje znacznie mniejsze napięcie niezadowolenia wśród proletariatu przemysłowego, co stoi niewątpliwie w związku z niskim uprzemysłowieniem kraju.

22 Obszerny biogram Izydora Schulza, przygotowany przez Tymoteusza Skibę, można znaleźć na stronie https://schulzforum.pl/pl/osoby/schulz-izydor (dostęp: 7 grudnia 2018).

23 M. Śliwa, Wpływ rewolucji 1905 roku na Galicję, „Przegląd Nauk Historycznych” 2005, nr 2 (8), s. 165.

24 W. Najdus, Rozwój ruchu strajkowego w Galicji w latach 1900-1914, "Przegląd Historyczny” 1957, $\mathrm{nr} 3$, s. 469. Por. eadem, Podłoże ruchu burżuazyjno-demokratycznego w Galicji w przededniu rewolucji 1905-1907 roku, "Przegląd Historyczny” 1955, nr 1-2, s. 41-98.

25 W. Najdus, Rozwój ruchu strajkowego w Galicji w latach 1900-1914, s. 469.

26 Ibidem, s. 470, 472. 
Lata wojny japońskiej i rewolucji odbijają się i tu groźnym pomrukiem. W 1904 roku strajkuje już 11 tysięcy, w 1905 i 1906 roku po 14 tysięcy”27.

Kiedy przegląda się numery „Tygodnika Samborsko-Drohobyckego” za rok 1905, wydarzenia te w zasadzie nie funkcjonują 28 (jakkolwiek informacje o wypadkach w Rosji i zaborze rosyjskim oczywiście się pojawiają, i to na pierwszych stronach, choć rzadziej, niż można by się spodziewać - i na pewno ocenzurowane). Za to uwagę przyciągają - wśród innych lokalnych wiadomości - informacje o samobójstwach, dzieciobójstwach, rozbojach, oszustach, pożarach, epidemiach (duru, szkarlatyny, tyfusu, zapalenia opon mózgowo-rdzeniowych), różnego rodzaju problemach i niedostatkach („W Drohobyczu znowu mięso wołowe podrożało z powodu braku bydła, a bydła brak z powodu zeszłorocznej posuchy. Uboższa ludność musi się wobec tego wyrzec mięsa i żyć chlebem, kartoflą i korzonkami” 9 kwietnia 1905, s. 2). Wreszcie w numerze z 3 grudnia 1905 roku natrafiamy na dwie frapujące wiadomości. Zasługują, by je przytoczyć niemal w całości:

„O strejku w Drohobyczu wszyscy nasi czytelnicy wiedzą z codziennych pism, przeto nie będziemy ich nudzić opisem szczegółowym. Zaznaczamy tylko, że ekscesów nie było wcale.

Nie możemy jednak milczeniem pominąć faktu, że mieszkańcy miasta Drohobycza, jakkolwiek nie wszyscy należą do partii socjalno-demokratycznej, usłuchali z iście baranią potulnością nakazu jakiegoś nikomu nieznanego komitetu, jak gdyby panowały u nas rządy terrorystyczne, których każdy słuchać musi z obawy o życie.

O rozgłaszanych tendencyjnie pogłoskach i o panice, która wskutek tego zapanowała w dniu 28 z [eszłego] m[iesiąca]., piszemy na wstępie numeru" (s. 2).

Tam zaś można przeczytać:

„Podczas gdy w całej monarchii austriackiej robiono przygotowania odpowiednie do spotkania się z manifestacją polityczną na 28 listopada b.r. naznaczoną przez partię socjalno-demokratyczną [...], w Drohobyczu wyszły na jaw okoliczności, których nie wolno pominąć milczeniem.

Od 2 lub 3 tygodni przed 28 listopada dzieci szkolne ruskich [tzn. ukraińskich] rodziców odgrażały się polskim i żydowskim uczniom, że na drugi tydzień bić się będzie Żydów i Polaków, a fama głosiła, że chłopom z okolicznych wsi rozdawano kartki z wezwaniem, by na dzień 28 listopada przybyli do miasta.

27 Z. Daszyńska-Golińska, Przyczynki do kwestii robotniczej w Polsce, Warszawa 1920, s. 29 (http:// rcin.org.pl/Content/33378/WA004_14818_U8821_Daszynska-Przyczynki_o.pdf; dostęp: 3 grudnia 2018). Zob. też "Naprzód” z 7 maja 1905 (nr 124), s. 1 i passim (https://docplayer.pl/57546462 Przeciwszwindlowi-kanalowemu.html; dostęp: 3 grudnia 2018); S. Bartoszewicz, Wspomnienia z przemysłu naftowego (1904-1905), „Przemysł Naftowy” 1934, z. 6, s. 146-152 (http://bc.inig pl:8080/dlibra/plain-content?id=2207; dostęp: 3 grudnia 2018).

28 Zob. https://www.pbc.rzeszow.pl/dlibra/publication/5411/edition/4979/content?ref=desc (dostęp: 3 grudnia 2018). 
Dzieci szkolne żydowskie opowiadały swoim rodzicom, że na ten dzień chłopi przyjdą do miasta z cepami i workami.

Na przedmieściach drohobyckich objawiało się burzliwe usposobienie, które we wysokim stopniu zaniepokoiło żydowskich mieszkańców [...].

Naturalnie, że pod wpływem tych groźnych, a we wysokim stopniu niepokojących wieści wszyscy kupcy, jakby się zmówili byli, postanowili zamknąć sklepy 28 listopada, a przez cały dzień poniedziałkowy bacznie śledzili usposobienie włościan, którzy się na targu jawili.

Nie przypuszczamy, ażeby o tych wieściach nie wiedziały władze bezpieczeństwa, [...] ale faktem jest, że społeczeństwo żydowskie, zaniepokojone owemi wieściami, domagało się rekwirowania wojska, a gdy w żaden sposób nie można się było dowiedzieć, czy to nastąpi - zaczęto myśleć o samoobronie i powszechnie zbrojono się w rewolwery. A gdy kilka bogatych rodzin żydowskich wyjechało z Drohobycza, ogólna zapanowała panika w społeczeństwie żydowskim, a po części wśród Polaków" (s. 1).

Nie sposób jednoznacznie rozstrzygnąć, czy opisane wypadki rzeczywiście dotknęły Schulza, ale równocześnie nie można wykluczyć, że tak się nie stało. Niezależnie od tego trudno przejść obok nich bez zadawania pytań o potencjalny wpływ atmosfery zagrożenia - jako pewnej stałej doświadczenia - na osobowość Schulza.

Warto byłoby też postawić kilka pytań okresowi, który nazwałam czasem względnej stabilizacji. Że nie musiał to być wcale łatwy okres w życiu Schulza, mogą świadczyć ogólne problemy, z którymi borykał się powojenny Drohobycz. Przykład pierwszy z brzegu. W „Chwili” z 10 listopada 1924 roku (nr 2031, s. 5) można przeczytać:

„W szczególności wniosło tutejsze Stowarzyszenie «Kupcy i Handlarze» jeszcze przed dwoma laty [...] odpowiednio uzasadniony memoriał [w sprawie zmiany kwalifikacji podatkowej miasta] [...].

Miasto bowiem Drohobycz było dotąd traktowane pod względem podatkowym jako miasto o rzekomo wybitniejszym ruchu handlowo-przemysłowym względnie jako miasto stanowiące centrum handlowo-przemysłowe w równym stopniu ze Lwowem, Krakowem i Łodzią. Ta nieuzasadniona klasyfikacja została chyba spowodowana okolicznością, że miasto nasze sąsiaduje bezpośrednio $\mathrm{z}$ zagłębiem naftowym $\mathrm{i}$ widocznie $\mathrm{z}$ tego lokalnego położenia swego ciągnąć ma tak znaczne korzyści gospodarcze i zasługuje na ustawowe wywyższenie go pod względem podatkowym do pierwszej klasy, jakkolwiek handel drohobycki nie stał w ścisłym związku przyczynowym z rozwojem przemysłu naftowego i jakkolwiek Drohobycz pod względem handlowym przedstawiał najzwyczajniejszą prowincjonalną mieścinę bez szczególnego znaczenia.

Drohobyczowi bowiem brak w ogólności handlu hurtownego, a targ towarowy nie przekracza przeciętnych małomiejskich granic, o czym świadczy okoliczność, iż Drohobycz wykazuje pewien mały ruch handlowy jedynie raz na tydzień 
w dniu targowym, a konsumenci rekrutują się wyłącznie już to ze średniego stanu mieszczańskiego, już to z głodującej inteligencji lub ludowych warstw robotniczych i włościańskich; zwłaszcza iż nieliczne zresztą warstwy zamożniejsze uskuteczniają swe zakupy we większych miastach poza Drohobyczem, a tak samo kopalnie lub przedsiębiorstwa naftowe sprowadzają artykuły swego zapotrzebowania $z$ różnych innych miejscowości przy ominięciu Drohobycza. Do tego przyłącza się zupełna stagnacja $\mathrm{w}$ przemyśle naftowym i w handlu, tak że Drohobycz spadł ostatnio do rzędu małych miasteczek"29.

Ta opisana w lokalnej prasie sytuacja, nawet jeśli pewne sformułowania zostały użyte tendencyjnie i nieco przerysowują obraz, wydaje się przekonująca. Warto też pamiętać, że zanim zniszczonemu wojną Drohobyczowi uda się odzyskać równowagę, otrząsnąć ze skutków inflacji z lat 1919-192330 i odczuć efekty reformy Grabskiego (1924), nadejdzie wielki kryzys (1929), który w Polsce będzie odczuwany przynajmniej do 1935 roku. Przejmujący obraz ukazują między innymi Pamiętniki bezrobotnych, ogłoszone przez Instytut Gospodarstwa Społecznego w 1933 roku $^{31}$. Czy możliwe, żeby te trudności - nawet jeśli nie dotykały Schulza bezpośrednio i równie dotkliwie jak znaczną część społeczeństwa w tamtym czasie - przeszły zupełnie bez echa, nie rodząc niepokojów o własną sytuację bytową?

Oczywiście do 1935 roku pewien rodzaj poczucia bezpieczeństwa zapewniał całej rodzinie Izydor Schulz. Bruno niejednokrotnie podkreślał to w korespondencji: „brat mój, który jest człowiekiem dobrze sytuowanym przyrzekł mi przyczynić się finansowo do wydania tej pracy tak, że część lub, gdyby być musiało, całość kosztów wziąłby na siebie” (KL I, 3, s. 39); „Brat mój utrzymywał mój dom tj. siostrę i siostrzeńca, był żywicielem całego szeregu rodzin, które teraz znalazły się bez gruntu pod nogami. Będzie teraz ciężko - sam nie wiem, co zrobię” (KL I, 39, s. 83); „Odumarł on nie tylko swojej rodzinie, którą pozostawil, ale i mnie i siostrze i siostrzeńcowi, których wszystkich utrzymywał" (KL I, 40, s. 84). Kiedy go zabrakło, Schulz z dnia na dzień musiał przejąć całą odpowiedzialność za rodzinę. Prawdopodobnie jedynym dostępnym mu sposobem sprostania tej sytuacji było - mimo wahań, pragnień, oczekiwań, ambicji - trzymanie się stałej posady, znanego środowiska, oswojonego miejsca. Choć taka decyzja wcale nie przynosiła upragnionego bezpiecznego osadzenia $\mathrm{w}$ świecie.

29 Zob. https://libraria.ua/numbers/6/25191/?PageNumber=5\&Articleld=916705 (dostęp: 3 grudnia 2018).

30 A. Faron, Przebieg inflacji markowej w II Rzeczypospolitej, "Studia Ekonomiczne" 2003, nr 26, s. 33-49.

31 Pamiętniki bezrobotnych. Nr 1-57, Warszawa 1933 (http://rcin.org.pl/dlibra/docmetadata?id=66646 \&from=publication; dostęp: 3 grudnia 2018). $Z$ punktu widzenia miejsc życia Schulza szczególnie interesujące są strony 510-600. 
Przejmująco brzmi list do Romany Halpern z 15 listopada 1936 roku: „Próbowałem zrezygnować z twórczości, żyć jak przeciętny człowiek i wydaje mi się to bardzo smutne. Prócz tego moja codzienna egzystencja zależy od mojej sztuki, gdyż walorami zapożyczonymi ze sztuki podpieram moje kalekie nauczycielstwo. Byłem już w myśli pozbawiony posady i w ostatniej nędzy. Patrząc na wariatów miejskich, na żebraków w łachmanach, myślałem: może wkrótce ja tak będę wyglądał. Wie Pani, że ja nie nadaję się do żadnej pracy uczciwej. Nie mogę się przemóc, nie mogę znaleźć żadnego uroku w nauczycielstwie. Tym się różnię wybitnie od moich kolegów-nauczycieli. [...] Obowiązki służbowe napełniają mnie grozą, wstrętem, mrożą radość z życia. Wśród tego bezrobocia słyszy się tylko groźby i napomnienia. Obowiązek urasta do jakichś apokaliptycznych rozmiarów. Groźba redukcji wisi nad każdym. Przed kilkoma laty można było w naszym zawodzie jeszcze odczuwać spokój bezpiecznego portu, jakiejś życiowej przystani. Było trochę pogody i radości. Teraz wypędzono radość z naszego życia, a bez radości, bez małej nadwyżki radości - nie umiem tworzyć” (KL I, 82, s. 141).

Jeszcze bardziej poruszający jest list do Halpern z 31 marca 1938 roku. Dzieje się tak za sprawą brutalnie lapidarnego odniesienia do społeczno-politycznej rzeczywistości, odniesienia, których niemal nie znajdujemy w korespondencji Schulza: „Jestem teraz bardziej zajęty szkołą niż dotychczas. Staram się nie dać moim władzom pretekstu do oddalenia mnie, ale to zdaje się daremne, gdyż w razie wejścia w ustawę prądów nurtujących nasz kraj - nie będą potrzebne preteksty" (KL I, 103, s. 172).

W takim kontekście niepokoje Schulza, jego troska o siebie i najbliższych choć w jakiś sposób nieporadna - wcale nie wydają się „maską nieudacznika”. Przeciwnie, równie dobrze można je zinterpretować jako rodzaj poświęcenia i odpowiedzialności za najbliższych, które wyrastały z racjonalnych przesłanek i życiowego doświadczenia.

\section{„Komfortowa” posada nauczyciela}

Decyzję Schulza o trwaniu w nielubianej pracy nauczyciela, „która poza stałym dochodem na przyzwoitym poziomie gwarantowała mu także państwową emeryturę"32, można więc traktować jako decyzję ze wszech miar zrozumiałą. Czy jednak - poza faktem wykonywania pracy, która nie dawała radości - Schulz rzeczywiście miał powody do utyskiwań, że obowiązki zawodowe go przytłaczają, odbierają energię, pozbawiają czasu i możliwości skupienia się na aktywności twórczej. Czy nie przesadzał w tym i nie desperował ponad miarę?33 
Na początek znowu warto oddać głos Schulzowi. Oto kilka cytatów w układzie chronologicznym ${ }^{34}$ :

Z 12 marca 1926 roku do władz szkolnych: „Będąc zatrudniony 35 godzinami nauki tygodniowo $\mathrm{w}$ Zakładzie państwowym nie może podpisany $\mathrm{z}$ potrzebną intensywnością pracować nad ostatecznym ugruntowaniem swych wiadomości do egzaminu i prosi, Wysokie Kuratorium raczy udzielić mu urlopu od 15-go bm. do złożenia egzaminu tj. końca kwietnia br." (KL II, 2, s. 228).

Z 15 marca 1934 do Waśniewskiego: „Obaj byliśmy na technice, obaj nie ukończyli jej i wylądowali w zawodzie nauczycielskim. [...] Czy i Wy uczycie robót ręcznych? Zbrzydło mi to, do wymiotów!" (KL I, 25, s. 64).

Z 24 marca 1934 do tego samego adresata: „Nie odpisałem Wam natychmiast, gdyż byłem zajęty przygotowaniami do lekcji pokazowej z robót ręcznych (stolarstwo), która wczoraj odbyła się w obecności wizytatora i instruktora fachowego - na szczęście wyszedłem $\mathrm{z}$ tej próby nieźle. Okropnie mnie to wszystko nudzi i chciałbym się jakoś od tego uwolnić. Na drugi rok dochodzą do tego roboty w metalu" (KL I, 26, s. 65-66).

Z 23 czerwca 1934 do tegoż: „Zgłosiłem się na kurs wakacyjny robót ręcznych 3-tygodniowy w Żywcu od 2 lipca. Nie wiem, czy pojadę, chociaż to jest dla mnie konieczne, ze względu na roboty metalowe w przyszłym roku, których nie umiem. Jakim cudem uniknęliście tego przedmiotu nauczania, który teraz wyparł rysunki?” (KL I, 30, s. 71). I w nawiązaniu do tej samej sprawy 28 sierpnia 1934: „Strasznie mi się nie chce wracać do szkoły. Rozpacz mnie ogarnia na myśl o robotach w metalu, o których nie mam bladego pojęcia. W ogóle cały ten kram mierzi mnie i nudzi do najwyższego stopnia" (KL I, 31, s. 72).

Z 14 września 1934 do tegoż: „Mam wyrzuty sumienia, gdy porównuję Waszą pracowitość z moim lenistwem. Tyle pracy w szkole i jeszcze taki nadmiar energii i przedsiębiorczości! W jaki sposób przyszedłem do robót ręcznych? Prosta rzecz: Automatycznie. Ten proces powolnej przemiany rysowników w robociarzy obserwować można we wszystkich gimnazjach państwowych, w których rysunki jako przedmiot nadobowiązkowy służą tylko do łatania etatu. W tutejszym gimnazjum jest obecnie, przy sztucznej i naciągniętej ekspansji tego przedmiotu: 12 godzin rysunków. A do etatu potrzeba 27 godzin!” (KL I, 32, s. 74).

Z 6 października 1934 do tegoż: „Mój urlop zdrowotny się skończył i zacząłem już pracę w szkole. Jednakowoż wniosłem podanie do Ministerstwa o urlop roczny celem napisania powieści i oczekuję odpowiedzi. [...] Jeżeli mi odmówią, to będzie naprawdę rozpacz, gdyż tak odwykłem przez wakacje od szkoły i bachorów, że nie mogę sobie z nimi całkiem dać rady i dokazują mi niemożliwie.

34 Szerzej Schulzem nauczycielem zajmuje się Katarzyna Warska, której zawdzięczam wiele istotnych przemyśleń na ten temat (między innymi po referacie Początki pracy nauczycielskiej Brunona Schulza, wygłoszonym podczas Dni schulzowskich w Gdańsku w 2018 roku). 
Prócz tego nie wiem, co będzie z robotami w metalu, których nie umiem. Są to ładne rzeczy - ładniejsze niż drzewo, ale trzeba by gdzieś elementów obróbki się nauczyć" (KL I, 34, s. 75).

Z 15 października 1934 do tegoż: „Dziękuję Wam za rady odnośnie do taktyki wobec chłopców w szkole. Nie, tak źle - nie jest. Złośliwości nie zauważam u nich, tylko naturalny w tym wieku temperament. Odbywam teraz 11-ty rok służby" (KL I, 35, s. 77).

Z 2 grudnia 1934 do Tadeusza Brezy: „Jestem bardzo zdeprymowany: urlop, na który tak liczyłem, nie został mi przyznany. Zostaję w Drohobyczu, w szkole, gdzie nadal hałastra będzie wyprawiała harce na moich nerwach. [...] Gdy mam na następny dzień przygotować lekcję, zakupić w składzie drzewa materiały - już całe popołudnie i wieczór są dla mnie stracone [...]. A ponieważ każdy dzień szkolny jest w ten sposób sprofanowany [...] - nie piszę" (KL I, 13, s. 53-54).

Z 18 grudnia 1934 do Waśniewskiego: „Rysuję, między lekcjami i konferencjami, gdyż i ja jestem nauczycielem i uczę robót ręcznych i rysunków. 30 godzin tygodniowo" (KL I, 24, s. 63).

Z 19 grudnia 1934 do Waśniewskiego: „Wszystkie starania okazały się bezskuteczne wobec uchwały Rady Ministrów wstrzymującej urlopy płatne. Bardzo mnie to przygnębiło, gdyż już zżyłem się z myślą urlopu, szkołę traktowałem jako prowizorium i zdawało mi się, że nie będę mógł z powrotem wrócić do zajęć szkolnych. Byłem jakiś czas zupełnie zniszczony" (KL I, 38, s. 81).

Zimą 1934/1935 roku do Wacława Czarskiego: „Nie wiem, czy długo jeszcze wytrzymam tę mordęgę. Nie jest to ta szkoła $\mathrm{z}$ dawnych czasów, ta prawdziwa idylla wśród zawodów - prawie że uboczne zajęcie, skromnie trzymające się na tle życia. Odkąd porosła w pierze, rozzuchwaliła się bezwstydnie, stała się wymagająca, ma coraz wyraźniej pretensję do wypełnienia sobą życia człowieka. Nie znosi konkurencji. Dawno straciła tę piękną skromność, która ją predestynowała na zawód zarobkowy ludzi posiadających jakąś misję, jakieś zadanie wzniosłe, a nie intratne. Co zrobić? Czy mam się wyrzec tego, co uważam za moją misję, za moje właściwe zadanie? Czy mam roboty ręczne uważać za metę i cel mych dążeń? Już z natury nie jestem stworzony na to, żeby stawiać opór, sprzeciwiać się, przeciwstawiać się czyjejś woli. Nie posiadam tej siły przekonania, tej ciasnej wiary w słuszność mej sprawy, która do tego jest potrzebna. Dlaczegóż skazany jestem - ja, przyjaciel natury i jej elementarnych przejawów - przeciwstawiać się jej, tłumić w dzieciach jej naturalne i piękne popędy i wybryki, jej żywiołowy wandalizm? Nie, ta walka z solidarną i sympatyczną bandą 26 chłopców (tyle ma każdy kurs) uzbrojonych w młotki, piły i heble - nie jest zaszczytną walką, a gwałtowne i rozpaczliwe środki terroru, do których się posuwam, ażeby ją w ryzach utrzymać, przejmują mnie wstrętem. Wychodzę z tego co dzień zbrutalizowany i brudny wewnętrznie, $\mathrm{z}$ niesmakiem do siebie i z tak gwałtownym ubytkiem energii, że parę godzin nie wystarczy, ażeby ją zregenerować. Zresztą po południu mam różne zajęcia w pracowni” (KL I, 57, s. 98-99). 
Z 16 marca 1935 do Waśniewskiego: „Nauka w szkole zbrzydła mi do ostatnich granic. Nie umiem uczyć. Nie cieszą mnie te marne rezultaty, które można (podobno) osiągnąć" (KL I, 40, s. 84).

Z 13 maja 1935 do Brezy: „Wpadłem od razu w kołowrót szkolny. Wizytator usadowił się w Drohobyczu i ciąży nam jak zmora" (KL I, 14, s. 55).

Do Truchanowskiego z 6 października 1935: „Mam bardzo mało czasu, gdyż uczę w szkole 27 godzin tygodniowo robót ręcznych" (KL I, 64, s. 110).

Do Halpern z 30 sierpnia 1937: „Obawiam się, że ten rok pracy szkolnej mnie zabije. Jak długo byłem młodszy i żywotniejszy, mogłem to jakoś wytrzymać. Teraz wyłazi mi to gardłem" (KL I, 90, s. 154).

Do tejże z 17 kwietnia 1938: „Moja przerwa w pisaniu tłumaczy się poza tym pobytem wizytatora w szkole" (KL I, 104, s. 174).

Do tejże z 18 stycznia 1938: „Miałem list od prof. Chwistka, w którym ofiaruje mi swoją pomoc w przeniesieniu się do Lwowa, ale do szkół powszechnych. Jakoś nie bardzo mi to się uśmiecha. Zrosłem się z Drohobyczem, przy tym boję się, że praca $w$ szkołach powszechnych $b$. przepełnionych, będzie mnie jeszcze bardziej męczyła" (KL I, 95, s. 161).

By ten obraz zweryfikować, sięgnęłam po pracę Teresy Jaroszuk Świat w szkole. Twórczość wspomnieniowa nauczycieli Polski Odrodzonej (1918-1939). Wybrałam tę pozycję nie bez powodu. Autorkę interesuje w niej bowiem „pełna satysfakcja z wykonywanego zawodu, poparta nadzieją na lepszą przyszłość”. W prezentowanym materiale doszukuje się informacji „o swoistym etosie zawodu nauczyciela” i wskazuje na jego wyznaczniki: „powołanie, szacunek dla ucznia, wiedzę”. Przywoływani przez nią „pamiętnikarze przyznawali, że wchodząc do klasy, wkraczali jakby w inny świat. Inny od rzeczywistości, która istniała poza murami szkoły. Inny, to znaczy lepszy, taki, który mógł wypełnić całe życie i dla którego warto było pracować"35. Uznałam, że ten afirmatywny pierwiastek pozwoli choć w jakimś stopniu zweryfikować postawę Schulza wobec pracy w szkole i jego poczucie przytłoczenia obowiązkami zawodowymi. Wyszłam z prostego założenia, że problemy opisywane przez nauczycieli spełniających się w swoim zawodzie można uznać za wiarygodne i tym samym zdjąć z Schulza odium kogoś, kto „nie postrzega [własnej sytuacji] w sposób obiektywny”36.

Jakie kwestie podnoszą więc przywoływani przez Teresę Jaroszuk nauczyciele?37 Przede wszystkim niewielki (niewystarczający) prestiż tego zawodu, związany z zarobkami, które były niższe niż w innych grupach zawodowych

35 T. Jaroszuk, Świat w szkole. Twórczość wspomnieniowa nauczycieli Polski Odrodzonej (1918-1939), Olsztyn 2005, s. 7.

36 P. Sitkiewicz, op. cit., s. 133.

37 Wielu bohaterów jej książki to osoby pracujące w wiejskich szkołach - ich relacje pomijam z oczywistych względów, podobnie jak nauczycieli prywatnych. 
o podobnym poziomie wykształcenia ${ }^{\mathbf{3 8}}$. Na ten brak należnego znaczenia w społeczeństwie wpływała także zależność nauczycieli zarówno od władz szkolnych różnych szczebli, jak i władz lokalnych i państwowych ${ }^{39}$, co ujawniało się między innymi w przesuwaniu nauczycieli do innych placówek „dla dobra szkoły” lub „na własną prośbę"40. Dodatkowo Ministerstwo Wyznań Religijnych i Oświecenia Publicznego „coraz bardziej odsuwało nauczycieli od rzeczywistej działalności wychowawczej, od ich indywidualnego, oryginalnego wpływu na działanie szkoły. Narzucało im rolę skrupulatnych realizatorów programów i wykonawców okólników, zarządzeń i przepisów"41. Pedagodzy byli przeciążeni nie tylko obowiązkami związanymi z pracą przy tablicy, ale również, zwłaszcza po 1932 roku, zadaniami wynikającymi z "programu wychowania państwowego" 42 , na które „składały się bardzo liczne imprezy okolicznościowe, rocznice historyczne dawnej i nowszej daty. Uroczystości te zmuszały nauczycieli i uczniów do częstego organizowania akademii, apeli, pogadanek, przemarszów ulicznych itp." $\mathbf{4 3}$. Nauczyciele borykali się też z kłopotami organizacyjnymi i finansowymi samych szkół ${ }^{44}$. Temu wszystkiemu towarzyszył chroniczny brak czasu.

$\mathrm{W}$ odniesieniu do tego ostatniego nie mogę się oprzeć pokusie przytoczenia pewnego cytatu znalezionego w książce Jaroszuk. Pochodzi on z powieści Wielki Tydzień (1939), napisanej przez wieloletnią nauczycielkę Eugenię Kobylińską-Masiejewską, i brzmi bardzo znajomo: ,jak zwykle doznała popłochu, gdy siadła przy swoim biurku. Wprost nie wiadomo było, od czego zacząć. [...] Nowe książki $\mathrm{z}$ dziedziny metodyki nauczania leżały już 3 tygodnie na biurku Masi, a ona nie miała czasu zabrać się do nich. Sama nie potrafiła określić, czy jest taka leniwa, czy niezaradna, czy ma takie życie trudne, że brak jej czasu na wszystko. Pewno kto inny umiałby jakoś jedno $\mathrm{z}$ drugim pogodzić, a ona nie może dopilnować tego, z czego chleb je. Nie pracuje nad sobą dalej. Przeżuwa dawną umysłową odżywkę. Niedługo stanie się anachronizmem w polskiej współczesności. Zupełnie się nie zdziwi, gdy wyniki jej pracy władza uzna za niedostateczne. Czasu, czasu jej braknie!”45.

Obraz pracy w szkole uzyskany na podstawie lektury książki Teresy Jaroszuk i przywoływanych przez nią materiałów o różnym charakterze nie odbiega - jak mi się wydaje - zasadniczo od tego, który wyłania się z listów Schulza prywatnych i do władz szkolnych, wreszcie ze sprawozdań rocznych gimnazjum drohobyc-

39 Ibidem, s. 15.

40 Ibidem, s. 20-21.

41 Ibidem, s. 16; por. też s. 20.

42 Ibidem.

43 Ibidem, s. 73.

44 Ibidem, s. 20.

45 Cyt. za: T. Jaroszuk, op. cit., s. 34; por. też przykład ze strony 83. 
kiego. Różnica polega na tym, że w wypowiedziach Schulza brak jakiegokolwiek afirmatywnego tonu związanego z pracą zawodową. Być może to właśnie sprawia, że tak trudno dostrzec, iż Schulz - choć swej pracy nie lubił - obowiązki wykonywał prawdopodobnie najlepiej, jak potrafił, z jakimś rodzajem odpowiedzialności i dbałością o swą pozycję zawodową.

Niemniej pozostaje pytanie: czemu tkwił $\mathrm{w}$ tak niekomfortowej dla siebie sytuacji? Nasuwa się przynajmniej kilka odpowiedzi i każda z nich obarczona jest podobnym ryzykiem przypisywania Schulzowi motywów, które nie były jego własnymi. Zatem czemu nie przyjąć za dobrą monetę słów pisarza z listu do Romany Halpern z czerwca 1939 roku: „Przez czas jakiś znajdowałem oparcie w myśli, że pójdę na drugi rok na emeryturę ( 40 procent pensji). Teraz odszedłem od tej myśli ze względu na rodzinę, której nie mógłbym wyżywić” (KL I, 115, s. 186)?

Praca nauczyciela w drohobyckim gimnazjum, jakkolwiek uciążliwa, niewdzięczna, niezbyt dobrze płatna, pozwalała Schulzowi w niepewnych czasach i nieprzyjaznym świecie zapewnić sobie i rodzinie pewien rodzaj (kruchej) stabilizacji. Ale nie musiał to być jedyny powód zakleszczenia pisarza i artysty w zawodzie nauczyciela. Schulz, zaczynając pracę w szkole, miał 32 lata, w 1936 roku, kiedy „dekretem Okręgu Szkolnego Lwowskiego został mianowany profesorem, co było szczytem kariery pedagogicznej w przedwojennej Polsce"46 - lat 44. Obawa przed rozpoczęciem wszystkiego od nowa (potęgowana i przez depresję, i przez słabe zdrowie, i wiele innych czynników), a nawet tkwienie w swego rodzaju pułapce utopionych kosztów - wszystko to wydaje się całkiem zrozumiałe i bardzo ludzkie. W dodatku trapiące Schulza „smutek życia, trwoga przed przyszłością, jakieś przeświadczenie niejasne o żałosnym końcu wszystkiego"47 nie wynikały tylko z depresji, z jakichś wewnętrznych demonów, lecz znajdowały aż nadto dużo pożywek w rzeczywistości - przeszłej i teraźniejszej, a i przyszłość, którą można było antycypować na podstawie wielu przesłanek, też nie rysowała się w jasnych barwach.

46 P. Sitkiewicz, s. 128. Por. KL I, s. 224.

47 Z listu do Zenona Waśniewskiego z 5 czerwca 1934, KL I, 29, s. 69-70. 